\title{
Grazing of ciliated protozoa on free and particle-attached bacteria
}

\author{
L. J. Albright ${ }^{1}$, E. B. Sherr ${ }^{2}$, B. F. Sherr ${ }^{2} \&$ R. D. Fallon ${ }^{2 *}$ \\ ${ }^{1}$ Department of Biological Sciences, Simon Fraser University, Burnaby, British Columbia V5A 1S6, Canada \\ ${ }^{2}$ Marine Institute, University of Georgia, Sapelo Island, Georgia 31327, USA
}

\begin{abstract}
We tested the grazing preference of natural assemblages and of isolated species of ciliated protozoa for free or for particle-attached bacteria. Bacterivorous ciliates were obtained from tidal creek water and from the surface flocculent layer of Spartina salt marsh sediments. Free and particle-attached bacteria were prepared by growing a Gram-negative, rod-shaped bacterium either in a nutrient solution, or on the surfaces of artificially made alginate beads containing the same nutrients. The free and particle-attached bacteria were stained with a fluorescent dye and offered separately to ciliates in trace amounts ( $5 \%$ of the natural bacterial abundance of $10^{6}$ to $10^{7}$ cells $\mathrm{ml}^{-1}$ ). Uptake of fluorescently labeled bacteria (FLB) by ciliates was monitored over 30 to 60 min periods. All ciliates tested, except for a Euplotes sp. isolated from marsh floc, fed equally well or better on free FLB than on attached FLB. The marsh floc ciliates showed a stronger preference for attached bacteria then did tidal creek ciliates. Small spirotrichous ciliates and a free-swimming peritrich present in creek water ingested free FLB at rates 12 to 36 times greater than found for attached FLB. Our experimental results indicate that bacterivorous ciliates are capable of feeding on free bacteria at bacterial abundances less than $10^{7} \mathrm{cells}^{-1}$, and may not, as presently thought, be confined to grazing attached or aggregated bacteria in natural waters.
\end{abstract}

\section{INTRODUCTION}

Protozoa have been identified as the dominant consumers of bacteria in aquatic ecosystems (Fenchel 1984, Sieburth 1984, Porter et al. 1985). Phagotrophic flagellated protozoa are currently thought to be the major grazers of suspended bacteria (Fenchel 1982, 1984), while ciliated protozoa are presumed to be important bacterivores only in sediments (Fenchel 1975,1980 ) or on particulate material in the water column (Caron et al. 1982, Sieburth 1984, Silver et al. 1984). Further, ciliates are thought to chiefly consume attached or aggregated bacteria, except at extremely high bacterial abundances $\left(>10^{7}\right.$ to $10^{8}$ cells $\mathrm{ml}^{-1}$ ) (Fenchel 1977, 1980, 1984, Sieburth 1984).

However, recent reports suggest that some ciliates may also graze free bacterioplankton. Several investigators, using a variety of techniques, have obtained evidence that pelagic aloricate ciliates, particularly small spirotrichous species, are capable of grazing sus-

\footnotetext{
- Present address: Haskell Laboratory for Toxicology and Industrial Medicine, PO Box 50, Elkton Road, Newark, Delaware 19711, USA
}

pended bacteria at in situ bacterial abundances (Borsheim 1984, Gast 1985, Lessard \& Swift 1985, Rivier et al. 1985, Sherr et al. 1986, Shen \& Sherr 1987). When pelagic ciliates were offered a natural food (fluorescently stained, monodispersed bacteria), measured clearance rates were 10 to 100 -fold greater (Sherr \& Sherr 1987) than earlier estimates of ciliate bacterivory determined using inorganic fluorescent beads (Fenchel 1980). These results indicate that ciliate populations in natural waters might indeed be significant consumers of free bacterioplankton, especially as small aloricate ciliates are ubiquitous and frequently abundant in marine waters (Sherr et al. 1986, and references cited therein).

The question of whether aquatic ciliates preferentially graze free or particle-attached bacteria at the concentrations commonly found in natural waters is also of interest since most (i.e. approximately 75 to $>90 \%$ ) bacterioplankton are unattached (Wiebe \& Pomeroy 1972, Zimmerman 1977, Bell \& Albright 1981, Albright et al. 1986).

We report herein the results of a series of experiments in which we directly tested the ingestion preference of some natural assemblages and cultures of 
estuarine ciliates for free and particle-attached bacteria. We used a simple approach of offering ciliates a fluorescently stained cultured bacterium, added in tracer amounts to the natural bacterial assemblage, either as free (monodisperse) cells, or as cells grown on, and attached to, artificially prepared particles (alginate beads). We tested ciliates both from the water column, and from the flocculent layer of salt marsh surface sediments. Previous studies have shown that in Georgia estuaries, most $(>90 \%)$ of the suspended bacteria in tidal creek water are free (Newell et al. 1987), while over $90 \%$ of bacteria in sedimentary floc are particleattached (Robertson \& Newell 1982). We therefore hypothesized that marsh floc ciliates would show a greater preference for feeding on attached bacteria than would pelagic ciliates.

\section{METHODS}

Free bacterial prey were prepared by inoculating $5 \mathrm{ml}$ of a $48 \mathrm{~h}$ culture of a Gram-negative bacterium isolated from a fresh water pond on Sapelo Island, Georgia, USA, into 11 of a medium composed of $300 \mathrm{mg}$ RNA (Kodak technical) and $300 \mathrm{mg}$ yeast extract (Difco), $\mathrm{pH}=7.2$, and incubating the cells for $72 \mathrm{~h}$ at $22>\mathrm{C}$ with a shaking rate of 50 strokes $\mathrm{min}^{-1}$. This medium was chosen because it supported adequate growth of the bacteria, yet did not readily leach from the alginate beads because of its particulate nature. The cells (short rods with an average cell size of $0.10 \mu \mathrm{m}^{3}, 0.6 \mu \mathrm{m}$ effective spherical diameter; Sherr et al. 1987) were then harvested by centrifugation and resuspended in $0.05 \mathrm{M} \mathrm{Na}_{2} \mathrm{HPO}_{4} / 0.85 \% \mathrm{NaCl}$ solution $(\mathrm{pH}=9)$ in preparation for fluorescent staining.

Beads of Ca-alginate were prepared by spraying $10 \mathrm{ml}$ of a $1 \%$ solution ( $\mathrm{pH}=7.2$ ) of alginic acid (Kelco) containing $300 \mathrm{mg}$ RNA (Kodak technical) $\mathrm{l}^{-1}$ and $300 \mathrm{mg}$ yeast extract (Difco) $\mathrm{l}^{-1}$ into $1 \mathrm{l}$ of a sterile 0.01 $\mathrm{M} \mathrm{CaCl}_{2}$ solution ( $\mathrm{pH}=7.2$ ). The alginic acid droplets immediately condensed with Ca cations to form insoluble Ca-alginate beads with most diameters varying from approximately 3 to $50 \mu \mathrm{m}$; a very few beads were between 50 and $95 \mu \mathrm{m}$ in diameter. Mean bead diameter was $29.2 \pm 1.1 \mu^{3}\left(\mathrm{SE}_{1} \mathrm{n}=200\right)$. This bead suspension was then inoculated with $5 \mu \mathrm{l}$ of a $48 \mathrm{~h}$ culture of the Gram-negative bacterial isolate and incubated as described above for $7 \mathrm{~d}$. Under these conditions bacteria grew on the surface of the microbeads, forming colonies of 2 to approximately 20 cells. The attached bacteria were approximately $0.5 \mu \mathrm{m}$ wide by 0.6 to $5.0 \mu \mathrm{m}$ long, with a mean biovolume of $0.32 \pm 0.03 \mu \mathrm{m}^{3}$ $(\mathrm{SE}, \mathrm{n}=53$ ). Beads with attached bacteria were harvested by centrifugation at $1000 \mathrm{rpm}$ for $5 \mathrm{~min}$ and the pellets resuspended in a $0.01 \mathrm{M} \mathrm{CaCl}_{2}$ solution contain- ing $0.05 \mathrm{M}$ Tris ( $\mathrm{pH}=9.0$ ) buffer by vigorous swirling. The beads were repelletized and resuspended in fresh $\mathrm{CaCl}_{2}$-Tris buffer 4 times in order to remove associated free bacteria. Microscopic inspection showed that about $1 \%$ of the total bacteria in the bead suspensions were free after this treatment.

Both the free and attached bacterial preparations were stained with the general protein fluorescent dye 5-(4,6-dichlorotriazin-2-y)amino-fluorescein

(DTAF) (Sigma) as described in Sherr et al. (1987).

To obtain natural ciliate assemblages, tidal creek water was collected from the upper Duplin River adjacent to Sapelo Island (Sherr et al. 1986), and the flocculent layer from marsh surface sediment was sampled using a hand pump at low tide in a Spartina alterniflora marsh near the Marine Institute. Three ciliate species were also cultured: a Uronema sp. was isolated from the tidal creek, and a mixed culture of a Euplotes sp. and a scuticociliate sp. was obtained from a bacterialenriched suspension of marsh floc. The ciliate cultures were maintained at $25^{\circ} \mathrm{C}$ on boiled wheat grain infusions (Rivier et al. 1985). In addition, we obtained a concentrated population of a free-swimming peritrich species in tidal creek water by gently screening $4 \mathrm{I}$ of water through $17 \mu \mathrm{m}$ Nitex netting, to a final volume of $400 \mathrm{ml}$.

Experiments to test the preference of intact ciliate assemblages or of the 3 cultured ciliate species for free or attached bacteria were run as follows: 4 replicate $100 \mathrm{ml}$ portions of the sample to be tested - tidal water, marsh floc $(5 \mathrm{ml}$ resuspended in $100 \mathrm{ml}$ of $0.2 \mu \mathrm{m}$ prefiltered seawater) and ciliate cultures (diluted with $0.2 \mu \mathrm{m}$ filtered seawater to yield 60 to 100 ciliates $\mathrm{ml}^{-1}$ ) - were incubated at $25^{\circ} \mathrm{C}$, approximately in situ tem. perature, in $400 \mathrm{ml}$ Whirl-pak plastic bags which had been previously presoaked in $10 \% \mathrm{HCl}$ and rinsed to neutrality in deionized water. Total bacterial concentrations of the samples were estimated by direct counts of DAPI-stained cells (Porter \& Feig 1980) after the bacteria had first been deflocculated and dispersed as described by Velji \& Albright (1986).

DTAF-stained free or bead-attached bacteria were then added to the $100 \mathrm{ml}$ samples in trace amounts (approximately $5 \%$ of the predetermined bacterial abundance, for a final concentration of FLB of 3 to $6 \times 10^{5}$ cells $\mathrm{ml}^{-1}$ ), 2 of the replicate bags receiving only free bacteria, and the other 2 only particle-attached bacteria. Addition of trace amounts of fluorescently labeled bacteria ensured that grazing rates of the ciliates were not unduly altered by increases in bacterial abundance. Subsamples of $5 \mathrm{ml}$ were removed from each of the 4 bags immediately after addition of the free or attached bacterial prey, and at 10 to $20 \mathrm{~min}$ intervals thereafter for periods of 30 to $60 \mathrm{~min}$. The subsamples were preserved with $2 \%$ final concen- 
tration of sodium tetraborate-buffered formalin, and stored at $5{ }^{\circ} \mathrm{C}$ in the dark until subsequent microscopic analysis, using a Zeiss Universal Epifluorescence Microscope with a $75 \mathrm{~W}$ xenon lamp and Zeiss filter sets 477702 (for DAPI fluorescence) and 477709 (for DTAF fluorescence).

One to $5 \mathrm{ml}$ of each time-series subsample was stained with DAPI, filtered onto $0.8 \mu \mathrm{m}$ NucleporeBlack membrane filters, and inspected at $500 \times$ using the DAPI filter set to locate ciliates (Sherr et al. 1986). When a ciliate was found, the magnification was increased to $1250 \times$ and the filters switched to the DTAF set for enumeration of fluorescently labeled bacteria within the ciliate's food vacuoles. About 20 to 40 ciliates were inspected for each sample. Rates of ingestion of free or particle-attached bacteria by ciliates were analysed by determining the average number of fluorescently labeled bacteria (FLB) in the food vacuoles of enumerated ciliates for each time interval, and then calculating a rate of uptake from the linear portion of the curve of FLB cell ${ }^{-1}$ versus time, using linear regression analysis. Significant differences between rates of bacterial uptake were determined using the Students t-test. Two separate preference indices were derived from the ratio of mean ingestion rates of free or of attached bacteria by ciliates in replicate bags for each experiment. The first preference index was based on numbers of bacteria ingested, and the second was weighted to account for the $4.2: 1$ difference in average biovolume of attached versus free bacteria.

\section{RESULTS AND DISCUSSION}

Microscopic examination showed that ciliate populations in the tidal creek were dominated by small ( 8 to $15 \mu \mathrm{m})$ aloricate spirotrichs. Scuticociliates such as Uronema sp. and a $30 \mu \mathrm{m}$ diameter free-swimming peritrich, which typically occurred as 2 attached cells, were also common in creek water. The most numerous ciliates in the marsh floc were 15 to $25 \mu \mathrm{m}$ long scuticociliates and a 20 to $30 \mu \mathrm{m}$ diameter Euplotes sp.

In every experiment, ciliates ingested attached bacteria at a lesser rate than they did free bacteria, with significant differences between the mean uptake rates $(p<0.01)$ except for Euplotes sp. (Table 1). In terms of numbers of added FLB ingested, both the natural assemblages and cultured species of ciliates, from both tidal creek water and from marsh floc, showed a marked preference for the free bacteria (Table 1). The preference was most evident for ciliate populations in tidal creek water; these small spirotrichs ingested free bacteria at a rate over 30 times that of their uptake of attached bacteria (Table 1). The only ciliate which showed no numerical preference for free over attached bacteria was the Euplotes sp. (Table 1).

When the numerical preference index was weighted for biovolume differences between free and attached bacteria, the Uronema sp. and marsh floc scuticociliates showed only a slight preference for consumption of free over attached bacteria, and the Euplotes sp. had a 3 to 1 preference for attached bacteria (Table 1). However,

Table 1. Rates of ciliate ingestion of free (monodisperse) fluorescently labeled bacteria (FLB) and of FLB attached to alginate beads, added in tracer amounts $(\sim 5 \%$ of the natural bacterial abundance) to estuarine water. Mean of 2 slopes $\pm 1 \mathrm{SD}$. Preference indices are based on ingestion rates, and are in terms of both numbers of bacteria, and of biovolume of bacteria taken up ciliate $^{-1} h^{-1}$

\begin{tabular}{|c|c|c|c|c|}
\hline \multirow[t]{2}{*}{ Ciliates } & \multicolumn{2}{|c|}{$\begin{array}{l}\text { Ciliate ingestion rate } \\
\left(\text { FLB ciliate }{ }^{-1} h^{-1}\right)\end{array}$} & \multicolumn{2}{|c|}{$\begin{array}{c}\text { Preference indices } \\
\text { (Free FLB ingestion: attached FLB ingestion }\end{array}$} \\
\hline & Free FLB & Attached FLB* & $\begin{array}{c}\text { Based on } \\
\text { nos. of FLB }\end{array}$ & $\begin{array}{l}\text { Based on } \\
\text { biovolume of FLB }\end{array}$ \\
\hline \multicolumn{5}{|l|}{ Tidal creek ciliates: } \\
\hline Natural assemblaqe & $32.7 \pm 13.7$ & $1.0 \pm 0.4^{\cdots}$ & $32.7: 1$ & $8.7: 1$ \\
\hline Natural assemblage & $28.5 \pm 4.3$ & $0.8 \pm 0.9 \cdots$ & $35.6: 1$ & $8.9: 1$ \\
\hline Free swimming peritrich & $200.0 \pm 7.0$ & $16.4 \pm 2.4^{\cdots}$ & $12.2: 1$ & $3.2: 1$ \\
\hline Uronema sp. & $7.3 \pm 0.2$ & $1.4 \pm 0.5^{\cdots}$ & $5.2: 1$ & $1.4: 1$ \\
\hline \multicolumn{5}{|l|}{ Marsh floc ciliates: } \\
\hline Natural assemblage & $3.4 \pm 0.7$ & $0.7 \pm 0.3 \cdots$ & $5.7: 1$ & $1.5: 1$ \\
\hline Scuticociliate sp. & $90.1 \pm 13.3$ & $16.7 \pm 2.2^{\cdots}$ & $5.4: 1$ & $1.4: 1$ \\
\hline Euplotes sp. & $14.5 \pm 4.1$ & $12.4 \pm 2.2^{\text {NSD }}$ & $1.2: 1$ & $0.3: 1$ \\
\hline \multicolumn{5}{|c|}{$\begin{array}{l}\text { - Rates corrected for uptake of free FLB present as a } 1 \% \text { contaminant of the attached FLB preparations, assuming ciliate } \\
\text { clearance rates of free bacteria were the same in both treatments } \\
\text { - Significant difference between mean uptake rates of free FLB and of attached FLB, } p<0.01 \\
\text { NSD: no significant difference }\end{array}$} \\
\hline
\end{tabular}


the tidal creek spirotrichs and peritrich had a significant positive preference for ingestion of free bacteria even with the weighted index (Table 1).

The results of our experiments conformed to some of our original expectations. Our initial hypothesis that marsh floc ciliates would have a greater affinity for grazing attached bacteria than would ciliates in creek water was verified by the data (Table 1). The Euplotes $\mathrm{sp}$., a member of a ciliate group known to feed on surfaces (Sieburth 1979), showed the strongest preference for grazing attached bacteria. Of the pelagic ciliates, the Uronema sp., typically associated with detrital material and sediments (Sieburth 1979, Fenchel 1980), had the greatest relative affinity for attached bacteria.

However, all of the species and assemblages of ciliates we examined were capable of phagocytizing free bacteria, ingesting equal or greater biovolumes of free than of attached FLB during the incubations (with the exception of the Euplotes sp.) (Table 1). This result is contrary to the idea that marine bacterivorous ciliates generally graze the 'lawn' of bacteria growing on particles in the water when free bacterial concentrations are less then about $10^{7}$ to $10^{8}$ cells $\mathrm{ml}^{-1}$ (Fenchel 1980 , 1984, Sieburth 1984). In our experiments, total bacterial concentrations in tidal creek water were between 6.2 and $6.8 \times 10^{6}$ cells $\mathrm{ml}^{-1}$, and in the marsh floc and ciliate culture experiments, 7.5 to $12.7 \times 10^{6} \mathrm{cells}^{-1}$. These values are within the range of bacterial abundances previously found in Georgia coastal waters (Newell \& Fallon 1982, Sherr et al. 1986), as well as in other nearshore and estuarine systems (Ferguson \& Rublee 1976, Wright \& Coffin 1983, Fuhrman \& McManus 1984, Albright et al. 1986). The mean biovolume of added free FLB cells, $0.10 \mu \mathrm{m}^{3}$, was also only slightly larger than the average size of bacteria in the water column and sediments of the Georgia coast, about 0.05 to $0.08 \mu^{3}$ (Newell \& Fallon 1982, Sherr et al, 1986).

It is possible that the ciliates were not able to graze bacteria from artificial alginate beads with the same facility as they would from natural detrital particles. We also do not know whether the ciliates preferentially ingested the cultured FLB over their natural bacterial prey. Addition of only trace amounts of FLB compared to the total population of suspended bacteria may have minimized the possibility of preferential grazing. However, for the purpose of this study, in which we compared ciliate uptake of the same bacterium offered as either free or attached cells, selectivity for FLB over natural bacteria should not have affected the preference indices obtained in our experiments.

The results of testing a handful of ciliate assemblages and species will not provide a definitive answer to the question of feeding preferences of marine bacterivor- ous ciliates, although this is the first instance in which such a direct assay has been attempted. In this study we obtained evidence that a variety of estuarine ciliates are capable of preferentially grazing free bacteria at natural bacterial abundances, supporting other recent observations of marine ciliates feeding on bacterioplankton (Gast 1985, Lessard \& Swift 1985, Rivier et al. 1985, Sherr et al. 1986, Sherr \& Sherr 1987). In addition, Caron $(1984,1987)$ has shown that some heterotrophic flagellates preferentially graze attached bacteria. Thus, current ideas regarding feeding preferences of aquatic protozoa: i.e. that small flagellates are the universally dominant predators of free bacteria, and that bacterivorous pelagic ciliates specialize on attached bacteria, need to be re-evaluated.

Acknowledgements. We thank anonymous reviewers for their comments on the manuscript. This research was supported by grants to E.B.S. and to L.J.A. from the Sapelo Island Research Foundation and to L.J.A. from the Natural Sciences and Engineering Research Council of Canada. Contribution No. 580 of the University of Georgia Marine Institute.

\section{LITERATURE CITED}

Albright, L. J., McCrae, S. K., May, B. E. (1986). Attached and free-floating bacterioplankton in Howe Sound, British Columbia, a coastal marine fjord-embayment. Apl. environ. Microbiol. 51: 614-621

Bell, C. R., Albright, L. J. (1981). Attached and free-floating bacteria in the Fraser River estuary, British Columbia, Canada. Mar. Ecol. Prog. Ser. 6: 317-327

Borsheim, K. Y (1984). Clearance rates of bacteria sized particles by freshwater ciliates measured with monodispersed fluorescent latex beads. Oecologia (Berl.) 63: $286-288$

Caron, D. A. (1984). The role of heterotrophic microflagellates in plankton communities. Ph.D. thesis, Woods Hole Oceanogr. Inst. and Mass. Inst. Tech., Woods Hole

Caron, D. A. (1987). Grazing of attached bacteria by heterotrophic microflagellates. Microb. Ecol. 12: in press

Caron, D. A., Davis, P. G., Madin, L. P., Sieburth, J. McN. (1982). Heterotrophic bacteria and bacterivorous protozoa in oceanic macroaggregates. Science 218: 795-797

Fenchel, T. (1975). The quantitative importance of the benthic microfiora on an Arctic tundra pond. Hydrobiologia 46: $445-464$

Fenchel, T (1977). The significance of bacterivorous protozoa in the microbial community of detrital particles. In: Cairns, J. (ed.) Aquatic microbial communities. Garland Publications, New York, p. 529-544

Fenchel, T. (1980). Suspension feeding in ciliated protozoa: feeding rates and their ecological significance. Microb. Ecol. 6: 13-25

Fenchel, T. (1982). Ecology of heterotrophic microflagellates. IV. Quantitative occurrence and importance as bacterial consumers. Mar Ecol. Prog. Ser. 9: 35-42

Fenchel, $T$ (1984). Suspended marine bacteria as a food source. In: Fasham, M. J. R. (ed.) Flows of energy and materials in marine ecosystems. Plenum Press, New York, p. $301-316$ 
Ferguson, R. L., Rublee, P. (1976). Contribution of bacteria to standing crop of coastal plankton. Limnol. Oceanogr. 21: 141-144

Fuhrman, J. A., McManus, G. B. (1984). Do bacteria-sized marine eukaryotes consume significant bacterial production? Science 224: 1257-1260

Gast, V (1985). Bacteria as a food source for microzooplankton in the Schlei Fjord and Baltic Sea with special reference to ciliates. Mar. Ecol. Prog. Ser. 22: 107-120

Lessard, E. J., Swift, E. (1985). Species-specific grazing rates of heterotrophic dinoflagellates in oceanic waters, measured with a dual-label radioisotope technique. Mar. Biol. 87: 289-296

Newell, S. Y., Fallon, R. D. (1982). Bacterial productivity in the water column and sediments of the Georgia (USA) coastal zone: estimates via direct counting and parallel measurement of thymidine incorporation. Microb. Ecol. 88: 33-46

Newell, S. Y., Fallon, R. D., Sherr, B. F., Sheer, E. B. (1987) Mesoscale temporal variation in bacterial standing crop, percent active cells, productivity and output in a saltmarsh tidal river. Proc. Soc. int. Limnol. 23: in press

Porter, K. G., Feig, Y. S. (1980). The use of DAPI for identifying and counting aquatic microflora. Limnol. Oceanogr. 25: 943-948

Porter, K. G., Sherr, E. B., Sherr, B. F., Pace, M., Sanders, R (1985). Protozoa in planktonic food webs. J. Protozool. 32: 409-415

Rivier, A., Brownlee, D. C., Sheldon, R. W., Rassoulzadegan, F. (1985). Growth of microzooplankton: a comparative study of bactivorous zooflagellates and ciliates. Mar. Micro. Food Webs 1: $51-60$

Robertson, J. R., Newell, S. Y. (1982). Experimental studies of particle ingestion by the sand fiddler Uca pugilator (Bosc). J. exp. mar. Biol. Ecol. 59: 1-21

Sherr, B. F., Sherr, E. B., Fallon, R. D. (1987). Use of monodis- persed, fluorescently labeled bacteria to estimate in situ protozoan bactivory. App. environ. Microbiol. 53: in press Sherr, E. B., Sherr, B. F., Fallon, R. D., Newell, S. Y. (1986). Small, aloricate ciliates as a major component of the marine heterotrophic nanoplankton. Limnol. Oceanogr. 3: $177-183$

Sherr, E. B., Sherr, B. F. (1987). High rates of consumption of bacteria by pelagic ciliates. Nature, Lond. 325:710-711

Sieburth, J. McN. (1979). Sea microbes. Oxford Press, New York

Sieburth, J. McN. (1984). Protozoan bacterivory in pelagic marine waters. In: Hobbie, J. E., Williams, P. J. (ed.) Heterotrophic activity in the sea. Plenum Press, New York, p. $405-444$

Silver, M. W., Gowing, M. M., Brownlee, D. C., Corliss, J. O. (1984). Ciliated protozoa associated with oceanic sinking detritus. Nature, Lond. 309: 246-248

Velji, I., Albright, L. J. (1986). Microscopic enumeration of attached marine bacteria of seawater, marine sediment, fecal matter, and kelp blade samples following pyrophosphate and ultrasound treatments. Can. J. Microbiol. 32: 121-126

Wiebe, W. J., Pomeroy, L. R. (1972). Microorganisms and their association with aggregates and detritus in the sea: a microscopic study. Mem. Ist. Ital. Idrobiol. Dott Marco de Marchi Pallanza 29 (Suppl.): 325-352

Wright, R. T., Coffin, R. B. (1983). Planktonic bacteria in estuaries and coastal waters of northern Massachusetts: spatial and temporal distribution. Mar. Ecol. Prog. Ser. 11: 205-216

Zimmerman, R. (1977). Estimation of bacterial number and biomass by epifluorescence microscopy and scanning electron microscopy. In: Rheinheimer, G. (ed.) Microbial ecology of a brackish water environment. Springer-Verlag, Heidelberg, p. 103-120

This article was presented by Dr. S. Y. Newell; it was accepted for printing on April 3, 1987 